\title{
LOCAL WISDOM-BASED 4-ON (VISION, ACTION, PASSION, AND COLLABORATION) MODEL IN COMPETENCIES OF MACHINING TECHNIQUE IN VOCATIONAL SECONDARY SCHOOLS
}

\author{
Haris Abizar ${ }^{1, *}$, Moh. Fawaid ${ }^{2}$, Muhammad Nurtanto ${ }^{3}$, Soffan Nurhaji ${ }^{4}$, Solis Setiyani ${ }^{5}$ \\ 1, 2, 3,4 Faculty of Teacher Training and Education, Universitas Sultan Ageng Tirtayasa, Jl. Ciwaru Raya, Cipare, Serang, \\ Banten 42117, Indonesia \\ ${ }^{5}$ Faculty of Health Science, Universitas Faletehan, Jl. Raya Cilegon No.KM. 06, Pelamunan, Kramatwatu, Serang, Banten \\ 42616, Indonesia \\ E-mail: harisabizar@untirta.ac.id * \\ *Corresponding Author
}

\begin{abstract}
This study aims to identify teacher competency needs and develop a local wisdom-based 4-ON (vision, action, passion, and collaboration) model in the competencies of machining technique in vocational secondary schools. The 4-ON model is a way to examine the professionalism of teachers in vocational secondary schools. The type of study is research and development, using the Richey and Klein model. The subjects are 26 vocational teachers of machining techniques. The data collection uses questionnaires and documentation. The questionnaire instrument is declared valid by 3 experts in content and tested with reliable results with a value of 0.82. The data analysis is quantitative descriptive. The study of the research and development are: (1) the teacher need for 4-ON (vision, action, passion, and collaboration) $79.81 \%$ response, the implementation of the local wisdom in learning $78.13 \%$ response, and six competencies machining technique expertise $80.48 \%$ response; (2) the local wisdom-based 4-ON model in the competencies of machining technique goes through 3 stages, namely development, process, and output for a result the professional and competent teacher.
\end{abstract}

Keywords: 4-ON model, local wisdom, machining technique

\section{INTRODUCTION}

Human resources and local wisdom are part of Indonesian vocational secondary schools' (VSS) revitalization. The teachers are the main part of human resources, having a big impact on the development of the students. Practice-oriented learning and authentic assessment are things that teachers must fulfill [1]. However, they also need the right and effective way to deliver materials to their students. The theory and practice materials reinforce each other so that students get the wanted study [2],[3]. Local wisdom can be used as an approach by the teachers in the learning process.

The local wisdom approach can be applied to machining technique skills. The teachers teach the students to have the competency of (1) machining techniques; (2) welding techniques; (3) metal casting techniques; (4) industrial mechanical engineering; (5) design and drawings techniques; and (6) metal fabrication and manufacturing techniques [4] through local wisdom. The process of combining the field of machining technique competencies with local wisdom emphasizes the mastery of knowledge, skills, attitudes, and values needed by the world of work [5]. This combination is a strong reason for students to improve their abilities in vocational secondary schools [6].

Local wisdom-based learning focuses on local potentials. The potentials are various in the form of industry, crafts, and other fields that require tools or machines to process them. Vocational secondary school expertise in machining techniques which is equipped with six skills can develop a technology suited to the need of local potential in Banten Province, Indonesia. Besides, strong behaviors and responsibilities have a positive impact on technology creation. Thus, local wisdom-based learning shapes the character of students in the 
aspect of (1) truth, (2) moral and effective, and (3) culture [7].

The aspect of local wisdom is the basis of teachers in educating students [8],[9]. They can integrate the elements of science with the culture of society to foster nationalism spirit in students [10]. Moreover, teachers can master some methods that can influence the learning process. Local wisdom-based learning can influence students experimentally (practice) to support their independent learning [11]. This condition makes local wisdom-based learning need to be included in curriculum development especially for vocational secondary schools so that the role of the business party and the industrial party is increasingly effective [12]. Thus, vocational school graduates' expertise in machining technique become skilled and competitive.

The achievement of local wisdom-based learning with the competency of machining technique skills is also to shape students' learning independence. The attitude is a social value that students need to apply to not only become vocationally competent but also have a sense of social responsibility, professional dedication, integrity, friendliness, and selfless dedication [13]. The same thing is explained by Billett [14] that vocational education provides students to focus on skills preparation to make the graduates able to compete in the world of work. The foundation of machining engineering science and professional attitudes are the basis for producing competent graduates.

The local wisdom applied in the machining engineering department requires professional teachers. Nowadays, professional teachers need skills and experience as a basis of excellence in solving the learning process problems [15],[16]. Therefore, as educators, they must have a high standard of professionalism, knowledge, attitudes, and skills [17]. The standards need to be prepared by teachers, especially vocational teachers majoring in machining techniques in Serang City. Besides, professional teacher development pays attention to the planning, process, and evaluation of learning. A measured and continuous self-reflection affects the learning process and study of teachers [18]. Planning, process, and evaluation are carried out collaboratively to produce a significant positive impact on the quality of teaching [19]. So, teachers who design, implement, and evaluate collaboratively among teachers can measure the quality of their teaching and foster selfintrospection to always improve their quality as an educator. The quality of teachers needs to be supported by technological competence as a basic guideline for teachers in vocational education [20].

Planning, implementation, and evaluation of learning can measure teacher competence. Teachers must have four competency qualifications such as pedagogic, professional, social, and personal [21]. However, vocational education teachers are added to the ability of expertise in the field of study [22]. If the competencies are owned, the teacher is not only competent in the field of science but also has a sublime ethic to become a professional teacher.

The role of the teacher, local wisdom, and competencies of machining techniques need to be explored in depth. Previous studies were still limited to skills in the field of mechanical technique which were mastered by teachers. However, this study is more comprehensive on integrating teachers, local wisdom, and competency in machining techniques through the 4-ON (vision, action, passion, and collaboration) model for teachers in teaching competency in local wisdom-based machining techniques. The 4-ON model is a concept that combines the three components of the teacher's role in educating through local wisdom on machining techniques to produce graduates who can develop regional potential in the field of machining techniques.

Thus, the model was researched to identify needs and develop a local wisdombased 4-ON in the competencies of machining technique skills for teachers in Banten Province, Indonesia. The aim produces data of teacher needs related to 4-ON in the learning of 
machining techniques through local wisdom. The data creates a model that combines the element of teacher quality, local wisdom, and machining technique competencies to produce professional teachers.

\section{METHOD}

This study used research and development design with Richey \& Klein model [23]. The procedure in this model consists of (1) development; (2) validation; and (3) use of the model. However, this research was only carried out at the development stage in order (1) needs analysis; (2) design; (3) data collection; and (4) the formation of models. The target of this study was teachers whose expertise is machining technique and working at Vocational Secondary Schools known as Sekolah Menengah Kejuruan (SMK) Negeri 2, SMK N 4, SMK N 6, SMK PGRI 1, SMK PGRI 2, and SMK Prisma. The respondents were 26 teachers selected by using the purposive sampling technique. The data were collected by questionnaires and documentation. The data collected was analyzed by using a quantitative descriptive approach. Figure 1 shows the 4-ON research concept.

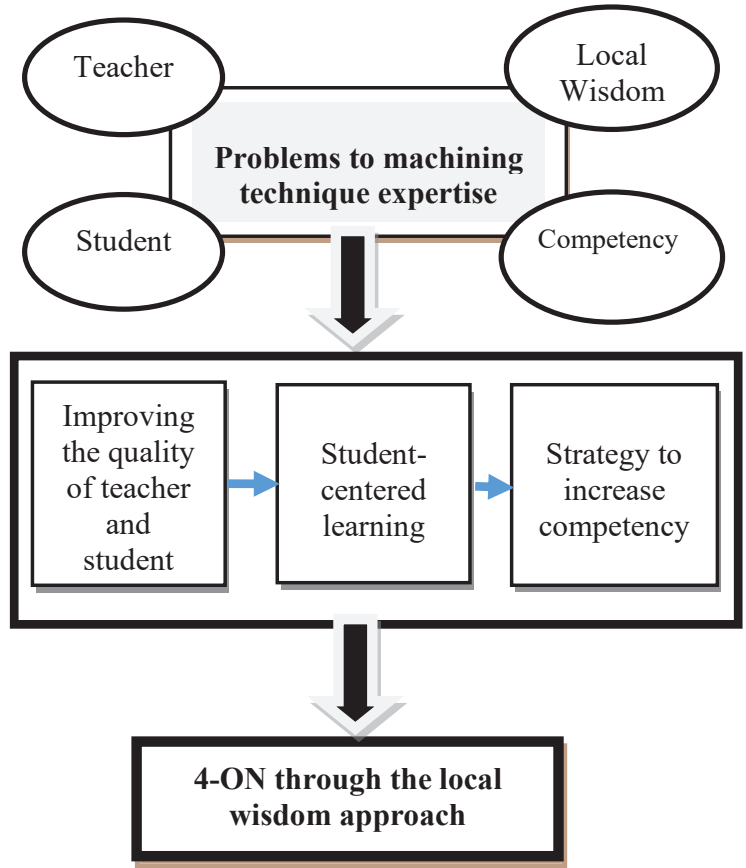

Figure 1. 4-ON Research Concept
The instrument used was tested for the level of validity and reliability. The content validity was carried out by 3 experts to validate the questionnaire instrument about the teacher's need for 4-ON, the implementation of local wisdom learning, and the field of machining technique expertise. The expert stated that the instrument is valid for use because there are no longer instruments that have been revised in content [24]. The results of the validity were carried out by the instrument reliability test using Cronbach's Alfa. The results show the test to the respondent with a value of 0.82 so that the instrument is declared reliable for use.

\section{RESULTS AND DISCUSSIONS}

Research and development of the 4-ON model is a learning mechanism that prioritizes teacher patterns in educating students by inserting elements of local wisdom in machining engineering expertise. This concept has 3 main components, they are (1) teachers who have a vision, action, passion, and collaboration; (2) local wisdom; and (3) competencies of machining technique skills. The components produce data to identify the needs of the teacher development model in the learning process.

Vocational secondary schools' revitalization in the aspect of human resources requires teachers to have vision, action, passion, and collaboration. The study of the identification of teacher aspect in Banten Province, Indonesia. Vocational secondary schools showed that all teachers agreed to have vision, action, passion, and collaboration as educators. It is a foundation for teachers to develop pedagogical, field of expertise, professional, social, and individual competencies. The 4-ON components for teachers are presented in Table 1.

Table 1 explains that most teachers agree to have vision, action, passion, and collaboration to become professional teachers. The data uses a Likert scale and is converted to a percentage becoming $79.81 \%$. It shows that 
the teachers must have a vision as a foundation of performance, planned and systematic action, a sense of passion, and collaboration. So, teachers can improve the quality of vocational education by creating competent graduates [25].

Table 1. 4-ON Components for Teachers

\begin{tabular}{clcc}
\hline No. & \multicolumn{1}{c}{ 4-ON Components } & Score & Category \\
\hline 1 & Vision & 3.22 & Agree \\
2 & Action & 3.31 & Very Agree \\
3 & Passion & 3.21 & Agree \\
4 & Collaboration & 3.01 & Agree \\
& Average & 3.18 & Agree \\
\hline
\end{tabular}

A synergistic 4-ON model implementation can form the professional character of the teachers [14],[26]. Vocational teachers with machining technique skills in Banten Province, Indonesia need a clear and measurable vision. Thus, the teacher's vision must involve the ability to pay attention and interpreting characters in the classroom interactions [27]. The abilities need to be designed by (1) following the development of vocational education; (2) determining the basis of instructional design and media; (3) measuring the level of success in educating; (4) changing paradigm as an educator; and (5) building teacher innovation and creativity.

The teacher's vision must be implemented in educating students. Appropriate and measurable actions are carried out by (1) building a competent teacher's soul; (2) providing innovative and creative materials; (3) developing innovative learning media; (4) becoming the role model for students. Teacher action required knowledge management systems in educating students on theoretical and practical material [28].

Teachers need a strong passion to do some actions as educators. They not only just run a routine but also must have a soul as a teacher [29]. Thus, they must teach with a sincere heart. The perceived effects are (1) fostering teacher creativity and innovation in teaching; (2) establishing teacher learning culture; (3) developing hard skills and soft skills; and (4) actively developing learning media.

Visions, actions, and heart desire as a teacher need to require collaboration among teachers. Professional teachers need to collaborate in the discussions of preparing the learning tools, the scientific disciplines, and the improvement of teacher professionalism. Collaboration involves teachers in mutual learning by planning, observing, and discussing learning outcomes [30] so the teachers must have the ability to adapt to the development of technology and have a certificate of expertise competency [31]. Therefore, the teachers can easily (1) improve their performance in educating; (2) increase their competencies; and (3) provide treatments according to the character of students in learning. Figure 2 presents the teachers' needs for 4-ON.

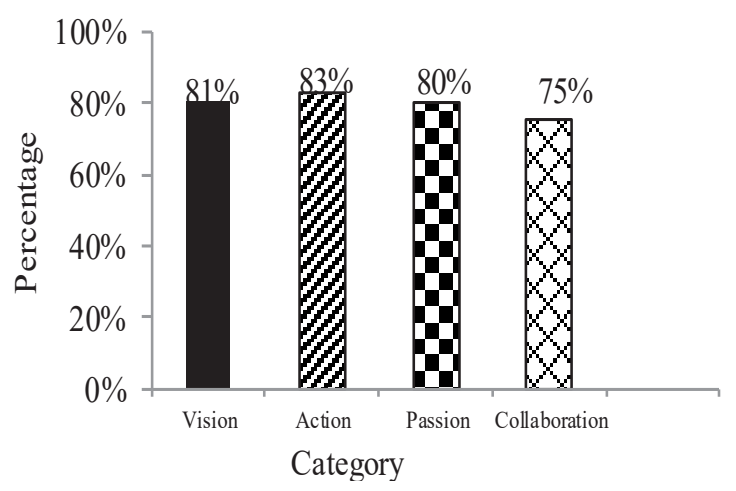

Figure 2. Teachers' Needs for 4-ON

The vision, actions, passion, and collaboration of teachers in machining technique skills must be adapted to local needs in Banten Province, Indonesia. The material taught, both theory and practice, must be suited to the local potentials. The need can be fulfilled by (1) identifying the local wisdom-related materials; (2) using appropriate teachinglearning strategies; (3) using project-based materials; and (4) imparting a strong character to develop local potentials [32],[33]. Teachers can deliver project-based materials such as making appropriate machines. The machines are made based on local needs in Banten 
Province, thus students can implement competency of machining, welding, metal casting, industrial mechanics, designing and engineering drawings, and metal fabrication and manufacturing into daily life.

It makes local wisdom-based learning needed by vocational teachers of machining techniques in Banten Province, Indonesia. The study showed $78.13 \%$ agreed to conduct local wisdom-based learning in machining technique vocational secondary schools. The condition is due to the abilities of local wisdom-based learning which can (1) improve the ability of students' knowledge, attitudes, and skills; (2) building a superior character of the teachers and the students; (3) develop the innovation of project-based learning tools; (4) contribute to the advancement of science; and (5) building production units that can be utilized by the community. Besides, local wisdom-based learning in vocational secondary schools needs to pay attention to students' needs, teacher quality, and the needs of the industrial or business world [34]. Figure 3 illustrates the local wisdom-based learning needs.



$\square$ Very Agree

Agree

[ Less Agree

- Disagree

Figure 3. Local Wisdom-Based Learning Needs

Local wisdom can be applied to projectbased learning. The learning model is suitable to be applied in vocational secondary schools, especially in machining techniques. The expertise has 6 competencies that need to be mastered by the teachers. The combination of competencies with local wisdom makes graduates having characteristics that can empower local potentials to be high-value products. Therefore, the teacher's need for six competencies of machining technique skills must be strengthened. It is approved by $80.48 \%$ of respondents who agreed that the competencies of the teachers should be strengthened. It can be realized by (1) developing innovative learning strategies on theoretical and practical materials; conducting project-based fieldwork practices; (3) taking the competency test; (4) joining intensive training for teachers; (5) managing an effective production unit.

Figure 4 describes the local wisdombased 4-ON model in machining technique skills. This model requires the machining technique teachers to carry out their profession. The need is obtained from the study of teachers' responses in improving their performance that supports vocational secondary school revitalization. They prioritize human resources improvement through the 4-ON concept (vision, action, passion, and collaboration). This concept relates to the competencies of the machining technique that apply local wisdombased learning. The teachers apply six machining technical competencies by producing products that meet local needs, especially in Banten Province.

Learning that prioritizes local wisdom such as making appropriate machines to produce souvenir products or traditional food processing. Making machinery requires the ability to design, operate production machinery (lathe, milling, welding, etc.), material science, and manufacturing technology. This ability is applied in learning to practice skills and keep local sustainability in Banten Province. Teachers use various strategies and adapt to the character of students so that individual abilities are achieved [35]. Besides, the learning process requires collaboration between students to organize product creation from design to product performance testing. Then, graduating students have competent hard skills and soft skills.

Therefore, teachers who have vision, action, passion, and collaboration can conduct effective learning. They teach and educate with a sense of sincerity and responsibility to produce active, innovative, creative, effective, 
and fun learning. Besides, teachers who can apply six competencies of machining techniques can prepare learning tools in a careful and structured manner. The toolkit contains designs, instruments, and materials that support local wisdom-based learning. The teachers creates graduates who have knowledge behavior, and skills needed by the world of work such as being an operator [36]. Thus, teachers educate students not only to direct graduates to be competent personnel but also to be able to produce products according to local needs.



Figure 4. Local Wisdom-Based 4-ON Model in Machining Technique Skill 


\section{CONCLUSION}

Teachers need 4-ON (vision, action, passion, and collaboration), local wisdom, and competencies in machining technique skills. The needs become the basis for the formation of the local wisdom-based 4-ON model in machining technique expertise through development, processes, and outcomes to be applied in theoretical and practical learning. The needs were obtained from the study of the teacher's response regarding the 4-ON concept as much as $79.81 \%$ and local wisdom-based learning as much as $78.13 \%$ by adjusting machining technique competencies as much as $80.48 \%$. Thus, the machining technique teachers agreed to the formation of the local wisdom-based 4-ON model with the stage of development, process, and output. The model is the basis for developing the quality of productive teachers in machining techniques.

\section{REFERENCES}

[1] J. Warwas and C. Helm, "Professional learning communities among vocational school teachers: Profiles and relations with instructional quality," Teach. Teach. Educ., vol. 73, pp. 43-55, 2018, doi: $10.1016 /$ j.tate.2018.03.012.

[2] M. Orozco, D. Gijbels, and C. Timmerman, "conceptualisation of integrative learning. a focus on theorypractice integration in technical vocational education and training," Vocat. Learn., vol. 12, no. 3, pp. 405424, 2019, doi: 10.1007/s12186-01909223-2.

[3] L. Valach, "Enacted mind, enminded and encultured action in vocational counseling: contextual action theory," Int. J. Educ. Vocat. Guid., no. $0123456789, \quad 2020, \quad$ doi: 10.1007/s10775-020-09432-5.

[4] Direktorat Jenderal Pendidikan Dasar dan Menengah, Spektum Keahlian Sekolah Menengah Kejuruan/Madrasah
Aliyah Kejuruan. Jakarta, Indonesia, 2018, p. 10.

[5] D. Wardiman, Pengembangan Sumber Daya Manusia Melalui Sekolah Menengah Kejuruan. Jakarta: PT Jayakarta Agung Offset, 1999.

[6] A. Volodina and G. Nagy, "Vocational choices in adolescence: The role of gender, school achievement, selfconcepts, and vocational interests," $J$. Vocat. Behav., vol. 95-96, pp. 58-73, 2016, doi: 10.1016/j.jvb.2016.07.005.

[7] Wagiran, "Pengembangan karakter berbasis kearifan local hamemayu hayuning bawana (identifikasi nilai-nilai karakter berbasis budaya)," J. Pendidik. Karakter, vol. 2, no. 3, pp. 329-339, 2012.

[8] M. C. M. M. L. Bontemps-Hommen, A. J. Baart, and F. J. H. Vosman, "Professional workplace-learning. can practical wisdom be learned," Vocat. Learn., vol. 13, no. 3, pp. 479-501, 2020,doi: 10.1007/s12186-020-09249-x.

[9] C. Pornpimon, A. Wallapha, and C. Prayuth, "Strategy challenges the local wisdom applications sustainability in schools," Procedia - Soc. Behav. Sci., vol. 112, no. Iceepsy 2013, pp. 626-634, 2014, doi: 10.1016/j.sbspro.2014.01.1210.

[10] J. Kidman, C. Yen, and E. Abrams, "Indigenous studens' experiences of the hidden curriculum in science education: a cross-national study in New Zealand and Taiwan," Int. J. Sci. Math. Educ., vol. 11, no. 1, pp. 43-64, 2013, doi: 10.1007/s10763-012-9365-9.

[11] Parmin, Sajidan, Ashadi, Sutikno, and Y. A. Maretta, "Preparing prospective teachers in integrating science and local wisdom through practicing open inquiry," J. Turkish Sci. Educ., vol. 13, no. 2, pp. 3-14, 2016, doi: 10.12973/tused.10163a.

[12] I. Indriaturrahmi and S. Sudiyatno, "The role of business and industry in the 
implementation of Vocational High School (VHS) based on local wisdom in the city of Mataram," J. Pendidik. Vokasi, vol. 6, no. 2, pp. 162-172, 2016.

[13] J. LI, "vocational core competencies of college students under the guidance of socialist core values," Stud. Sociol. Sci., vol. 7, no. 6, pp. 32-36, 2016, doi: $10.3968 / 9164$.

[14] S. Billett, Vocational Education: Purposes, Traditions and Prospects, $1 \mathrm{st}$ ed. New York: Springer Netherlands, 2011.

[15] J. Baggini, "What professionalism means for teachers today?," Educ. Rev., vol. 18 , no. 2, pp. 5-11, 2005.

[16] P. H. Phelps, "The three rs of professionalism," Kappa Delta Pi Rec., vol. 42, no. 2, pp. 69-71, 2006, doi: $10.1080 / 00228958.2006 .10516436$.

[17] N. Demirkas, "Defining ' teacher professionalism , from different perspectives," in Procedia Social and Behavioral Sciences, 2010, vol. 9, pp. 2047-2051, doi: 10.1016/j.sbspro.2010.12.444.

[18] C. Girvan, C. Conneely, and B. Tangney, "Extending experiential learning in teacher professional development," Teach. Teach. Educ., vol. 58, pp. 129-139, 2016, doi: $10.1016 /$ j.tate.2016.04.009.

[19] J. Gore, A. Lloyd, M. Smith, J. Bowe, H. Ellis, and D. Lubans, "Effects of professional development on the quality of teaching: Results from a randomised controlled trial of Quality Teaching Rounds," Teach. Teach. Educ., vol. 68, pp. 99-113, 2017, doi: 10.1016/j.tate.2017.08.007.

[20] J. P. Carpenter et al., "What should teacher educators know about technology? Perspectives and selfassessments," Teach. Teach. Educ., vol. 95, p. 103124, 2020, doi: $10.1016 /$ j.tate 2020.103124 .
[21] R. Bakar, "The influence of professional teachers on Padang vocational school students' achievement," Kasetsart $J$. Soc. Sci., vol. 39, no. 1, pp. 67-72, Jan. 2018, doi: 10.1016/J.KJSS.2017.12.017.

[22] S. Surono and W. Wagiran, "The profile of vocational high school teachers of the machining engineering and its relevance to the curriculum of mechanical engineering education study program, Faculty of Engineering, Yogyakarta State University," J. Pendidik. Vokasi, vol. 6, no. 1, pp. 94-110, 2016.

[23] R. C. Richey and J. D. Klein, Design and development research. London: Lawrence Erlbaum Associates. Inc., 2010.

[24] J. R. Fraenkel, N. E. Wallen, and H. H. Hyun, How to Design and Evaluate Research in Education, 8th ed. New York: McGraw-Hill Companies, Inc, 2012.

[25] Suharno, N. A. Pambudi, and B. Harjanto, "Vocational education in Indonesia: History, development, opportunities, and challenges," Child. Youth Serv. Rev., vol. 115, no. May, p. 105092, 2020, doi: 10.1016/j.childyouth.2020.105092.

[26] L. T. Tran and T. T. T. Le, Teacher Professional Learning in International Education: Practice and Perspectives from the Vocational Education and Training Sector. Switzerland: Palgrave Macmillan, 2018.

[27] M. G. Sherin and E. A. Van Es, "Effects of video club participation on teachers' professional vision," J. Teach. Educ., vol. 60, no. 1, pp. 20-37, 2009, doi: $10.1177 / 0022487108328155$.

[28] A. Saraswati, I. Hermadi, and S. H. Wijaya, "Development of knowledge management system of teachers' competency," J. Pendidik. Teknol. dan Kejuru., vol. 25, no. 1, pp. 124-131, 2019, doi: 10.21831/jptk.v25i1.23575. 
[29] A. Moè, "Harmonious passion and its relationship with teacher well-being," Teach. Teach. Educ., vol. 59, pp. 431-437, 2016, doi: 10.1016/j.tate.2016.07.017.

[30] H. Abizar, Buku Master Lesson Study, 1st ed. Yogyakarta: Diva Press, 2017.

[31] N. Absari, "The effectiveness of Technology, Pedagogy and Content Knowledge (TPACK) in learning," vol. 26, no. 1, pp. 43-51, 2020.

[32] P. Anggraini and T. Kusniarti, "Character and local wisdom-based instructional model of bahasa Indonesia in vocational high schools," $J$. Educ. Pract., vol. 8, no. 5, pp. 23-29, 2017.

[33] D. Guile and L. Unwin, The Wiley Hanbook of Vocational Education and Training. USA: John Wiley \& Sons, Inc, 2019.
[34] S. Billett, "The standing of vocational education: sources of its societal esteem and implications for its enactment," J. Vocat. Educ. Train., vol. 66, no. 1, pp. 1-21, 2013, doi: $10.1080 / 13636820.2013 .867525$.

[35] S. Mikkonen, L. Pylväs, H. Rintala, P. Nokelainen, and L. Postareff, "Guiding workplace learning in vocational education and training: a literature review," Empir. Res. Vocat. Educ. Train., vol. 9, no. 9, pp. 1-22, 2017, doi: 10.1186/s40461-017-0053-4.

[36] B. S. Wijanarka, D. Rahdiyanta, and T. Habanabakize, "The task of machine tool operation in small and medium enterprises in Indonesia," $J$. Pendidik. Teknol. dan Kejuru., vol. 24, no. 1, pp. 39-45, 2018, doi: 10.21831/jptk.v24i1.18004. 